\title{
Detection of c-Ki-ras gene codon 12 mutations from pancreatic duct brushings in the diagnosis of pancreatic tumours
}

\author{
J-L Van Laethem, P Vertongen, J Deviere, J Van Rampelbergh, F Rickaert, M Cremer, \\ P Robberecht
}

\begin{abstract}
Differential diagnosis of pancreatic cancer and chronic pancreatitis is sometimes difficult and cytological examination of brushings or aspirated material collected during endoscopic retrograde cholangiopancreatography (ERCP) remains disappointing. As point mutations in codon 12 of the c-Ki-ras 2 gene are found in most pancreatic adenocarcinoma and not in chronic pancreatitis, this study analysed prospectively the presence of these mutations in brushing samples collected during ERCP in 45 patients ( 26 males, 19 females) showing a dominant stricture of the main pancreatic duct at pancreatography: 24 with pancreatic adenocarcinoma, 16 with chronic pancreatitis, and five intraductal mucin hypersecreting neoplasms. Twenty of 45 patients presented equivocal ERCP findings that did not permit a definite diagnosis. Ki-ras mutations at codon 12 were detected using a rapid and sensitive method based on polymerase chain reaction mediated restriction fragment length polymorphism analysis and confirmed by direct sequencing of polymerase chain reaction products. Results were compared with those provided by routine brush cytology. A definitive diagnosis was established for each patient. Mutations were detected in 20 of 24 patients with pancreatic adenocarcinoma $(83 \%)$, but in none of the chronic pancreatitis patients and intraductal mucin hypersecreting neoplasms, irrespective of their location. By contrast, only 13 of 24 pancreatic adenocarcinoma $(54 \%)$ were detected by conventional cytological examination, which yielded four false negative and seven non-contributive results. Sensitivity, specificity, and accuracy of molecular biological and cytological methods were $83 \%-76 \%, 100-83 \%$, and $90 \%-58 \%$, respectively. Notably the mutations could be detected in six patients with small tumour size $(\leqslant 2 \mathrm{~cm})$. In conclusion, $\mathrm{Ki}-$ ras analysis performed on pancreatic brushing samples is an efficient procedure, more accurate than cytology in the diagnosis of pancreatic adenocarcinoma, and highly specific in the differentiation between neoplastic and chronic inflammatory ductal changes, especially in patients showing inconclusive ERCP findings.

(Gut 1995; 36: 781-787)
\end{abstract}

Keywords: Ki-ras gene mutation, endoscopic retrograde cholangiopancreatography, pancreatic cancer, chronic pancreatitis.

Despite considerable advances in imaging techniques, early diagnosis of pancreatic adenocarcinoma particularly in the setting of chronic pancreatitis remains elusive. Clinicians are often faced with unresectable tumours with a rapidly fatal outcome. ${ }^{1}$ A recent report of increased pancreatic adenocarcinoma risk in chronte pancreatitis patients has renewed the interest in early tumour diagnosis and in the differentiation between neoplastic and chronic inflammatory ductal changes. ${ }^{2}$

No currently available diagnostic modality is infallible. Endoscopic retrograde cholangiopancreatography (ERCP) is highly accurate in the diagnosis of pancreatic adenocarcinoma and its distinction from chronic pancreatitis, providing both sensitivity and specificity of more than $90 \% .^{3-4}$ While endoscopic ultrasonography has a high yield in small tumour $(\leqslant 25 \mathrm{~mm})$ detection it lacks adequate specificity. ${ }^{5-6}$ Cytological confirmation of radiographic findings is usually required, however, for the definitive diagnosis. The accuracy of cytological examinations performed on main pancreatic duct brushings or pancreatic juice sampled during ERCP is limited by a low sensitivity (ranging from 50 to $76 \%$ ). ${ }^{7-9}$

The Ki-ras oncogene is activated by specific point mutations restricted to codon 12 in 75 to $100 \%$ of pancreatic adenocarcinoma. ${ }^{10-13}$ Interestingly, these mutations seem to occur at an early stage of the neoplasm as well as a preneoplastic change. ${ }^{14-15}$ In the era of molecular biology, this finding might be sought to improve our diagnostic approach. An attempt at diagnosis, based on detection of this genetic change has already been performed in fine needle tumour aspirates or pancreatic juice samples with promising preliminary results. ${ }^{16} 17$

In this study, we prospectively analysed the frequency of the codon 12 changes of c-Ki-ras 2 gene in brushing samples collected during ERCP in patients showing a dominant stricture of the main pancreatic duct related to pancreatic adenocarcinoma or chronic pancreatitis. As a significant number of subjects presented equivocal ERCP findings, we compared the results of genetic analysis with those obtained by routine cytological examination in an attempt to differentiate malignant from benign lesions. Similarly, we studied five 


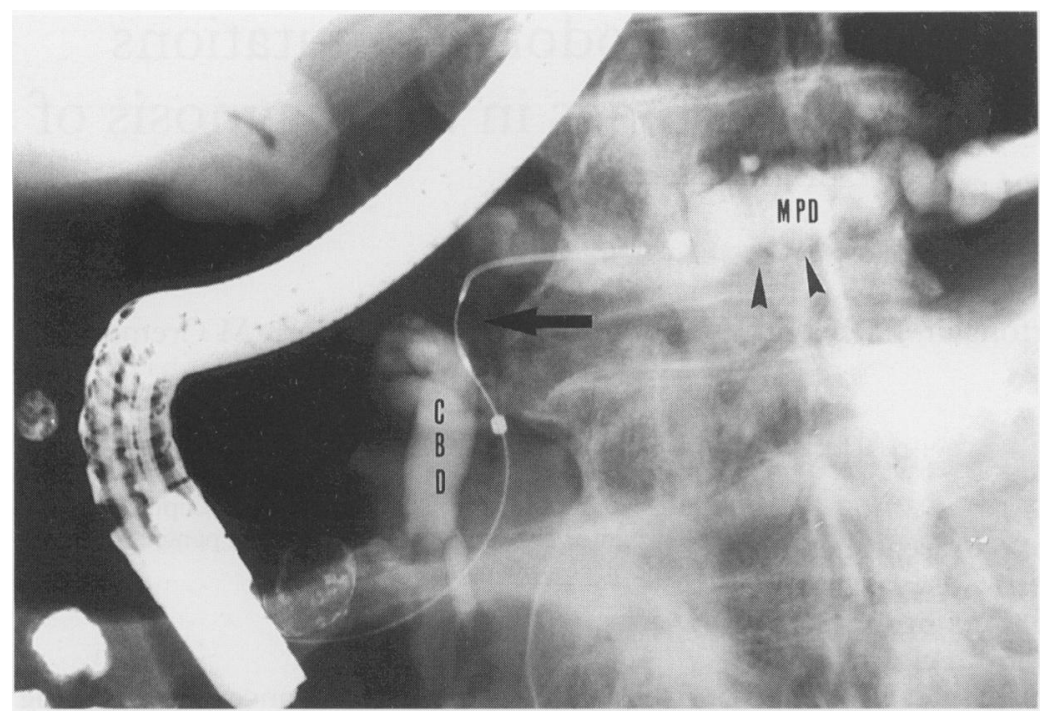

Figure 1: Cytology brush (large arrow) strategically placed within a main pancreatic duct stricture. The main pancreatic duct is dilated in its body segment above the stricture (arrowheads) next to the flexible guide tip. $C B D=$ common bile duct.

additional cases of intraductal mucin hypersecreting neoplasms, exhibiting ductal abnormalities at pancreatography. Because these tumours are considered to have a good prognosis but may undergo malignant transformation, ${ }^{18}$ we found it of interest to investigate a new genetic marker, which might predict their behaviour and prognosis.

\section{Methods}

PATIENTS

From November 1992 to December 1993, 45 patients (26 males, 19 females) receiving ERCP at our hospital were included: 24 patients with pancreatic adenocarcinoma (mean age: $69 \cdot 1$ years, range $41-79$ ), 16 with chronic pancreatitis (mean age: 49.4 years, range 35-73), and five with intraductal mucin hypersecreting neoplasm (mean age: 62.5 years, range 55-70). All exhibited a dominant stricture of the main pancreatic duct or duct clogging with mucoid material (in the case of intraductal mucin hypersecreting neoplasm). Twenty of 45 patients presented equivocal ERCP findings that did not permit a definite diagnosis of malignancy (see Tables I-III).

For each patient, a definitive diagnosis was established. The diagnosis of pancreatic adenocarcinoma was confirmed histologically in 16 of 24 patients, including 14 ductal adenocarcinoma and two cystadenocarcinoma. Eight other patients had unresectable pancreatic carcinoma as evidenced by endoscopic ultrasonography or computed tomography and by a rapidly worsening clinical course (detailed in Table II).

The diagnosis of chronic pancreatitis was supported by standard techniques (biochemical, computed tomography, and endoscopic ultrasonography and mainly by a favourable clinical outcome (detailed in Table I). All patients were clinically and radiologically followed up for at least six months (mean (SD) follow up: $9 \cdot 3(2 \cdot 2)$ months) without evidence of a worsening status.
Diagnosis of intraductal mucin hypersecreting neoplasm was established histologically after laparotomy in two of five patients; three patients had typical previously described clinical, endoscopic, and cytological findings ${ }^{18}$ - that is, relapsing pancreatitis like symptoms, widely open ampulla of Vater filled with mucoid material, multicystic dilations of the main pancreatic duct with patchy filling defects at pancreatography, and presence of exfoliated mucin rich tall columnar cells in abundant mucoid material at cytological examination.

\section{SAMPLING TECHNIQUE}

Diagnostic ERCPs were performed using an Olympus TJF-100 duodenoscope; lesions were identified after injection of iodinated contrast agent. Pancreatic duct brushings were collected with a Geenen cytology brush system (Wilson-Cook, Winston-Salem NC), fluoroscopically positioned through the suspected lesion (Fig 1). The brush was moved briskly several times over epithelium and then withdrawn into the outer sheath, aspirating additional epithelial cells. The procedure avoided contamination of the sample with cells from irrelevant sites (for example, duodenal tract) during brush withdrawal. Brushings were systematically obtained in duplicate for genetic analysis and routine cytological examination. Specimens were immediately collected in $5 \mathrm{ml}$ of phosphate buffered saline (PBS) at $4^{\circ} \mathrm{C}$ for DNA analysis or smeared on slides, fixed in $85 \%$ isopropyl alcohol, and stained by the Papanicolaou technique for concomitant standard cytological examination. Adequate material was obtained in each patient.

\section{DNA PREPARATION}

Samples were centrifuged at $2000 \mathrm{rpm}$ for 15-20 minutes to collect cells. Cell pellets were resuspended in $50-100 \mu l$ of a TRIS $0.1 \mathrm{M}$, EDTA $0.05 \mathrm{M}, \mathrm{pH} 8$ buffer containing $0.1 \mathrm{mg} / \mathrm{ml}$ proteinase $\mathrm{K}$ (Sigma) and incubated at $42^{\circ} \mathrm{C}$ for two hours. Proteinase $\mathrm{K}$ was then inactivated by boiling the samples at $95^{\circ} \mathrm{C}$ for 10 minutes. Proteinase $\mathrm{K}$ digests were centrifuged at $10000 \mathrm{rpm}$ for five minutes and $10 \mu \mathrm{l}$ of the supernatant was submitted to a polymerase chain reaction amplification.

POLYMERASE CHAIN REACTION-RESTRICTION FRAGMENT LENGTH POLYMORPHISM ANALYSIS c-Ki-ras mutations at codon 12 were detected using restriction fragment length polymorphism artificially introduced by the use of modified polymerase chain reaction primers as previously described ${ }^{19} 20$; the two primers used were a 22 mer $\left(5^{\prime}\right.$ TAAACTTGTGGTAGT TGGAGCC $3^{\prime}$ ) and a 20 mer ( $5^{\prime}$ TCTATT GTTGGATCATATTC $3^{\prime}$ ); substitution of $\mathrm{C}$ for $\mathrm{T}$ at the $3^{\prime}$ end of the 22 mer introduces an artificial Msp I restriction site (CCGG) when normal Ki-ras sequences are amplified but not when there is a mutation in the first or second position of codon 12. Thus, genomic DNA was amplified by the polymerase chain 


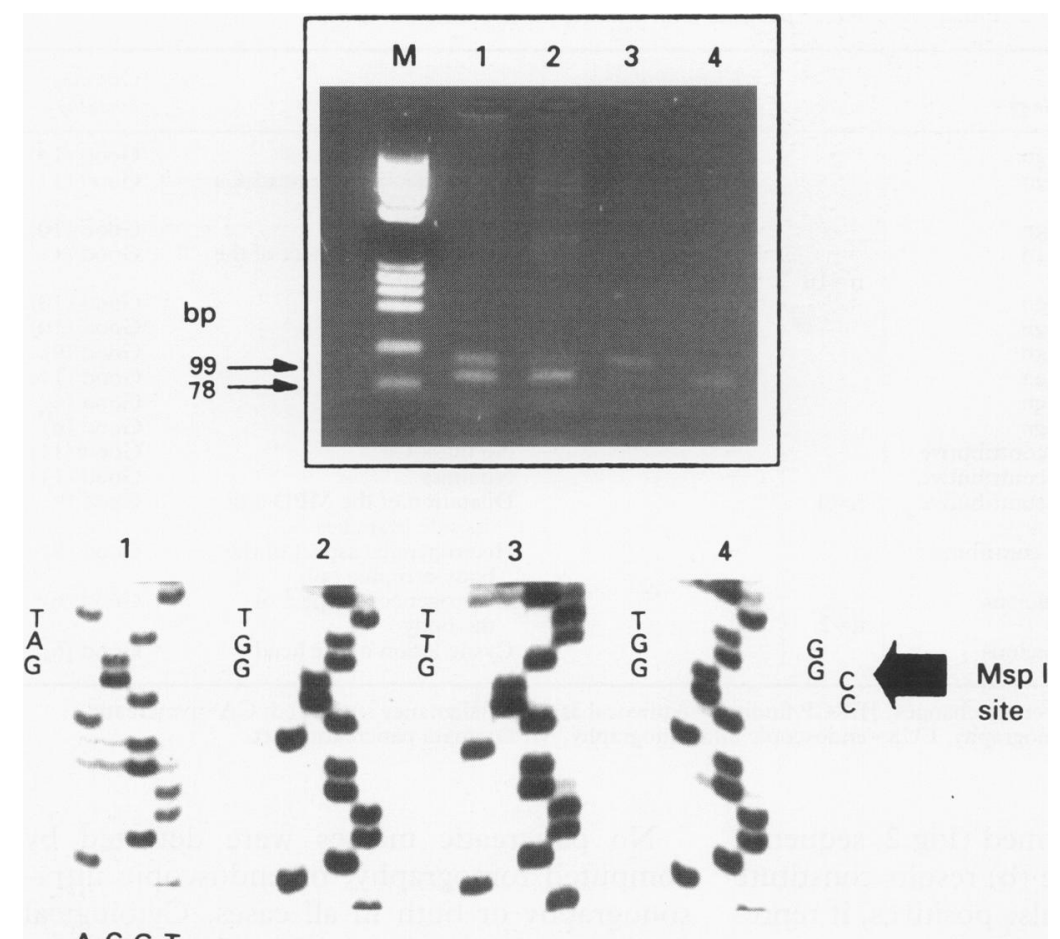

A C G T

Figure 2: Detection of point mutations at codon 12 by polymerase chain reaction-restriction fragment length polymorphism analysis and direct sequencing (DS): lane 1: both $99 \mathrm{bp}$ and 78 bp bands of similar intensity = positive result confirmed by $D S: G G T \rightarrow G A T$; lane 2: faint 99 bp band/dominant 78 bp band =false positive result invalidated by DS: GGT; lane 3: dominant 99 bp band/very faint 78 bp band=positive result confirmed by DS: $G G T \rightarrow G T T$; lane 4: single 78 bp band =negative result verified by $D S: G G T . M=D N A$ size ladder; $C C G G=M s p I$ cutting site in normal Ki-ras sequence.

reaction technique using the two primers in a $100 \mu \mathrm{l}$ amplification reaction containing $10 \mathrm{mM}$ TRIS- $\mathrm{HCl}$ (pH 8.3), $50 \mathrm{mM} \mathrm{KCl}$, $2.5 \mathrm{mM} \mathrm{MgCl}, 100 \mu \mathrm{M}$ of each dATP, dCTP, dGTP, dTTP, and five units of Ampli TAQ DNA polymerase. Reactions were incubated in a Perkin-Elmer/Cetus DNA thermal cycler for 35-40 cycles (denaturation: $1 \mathrm{~min}$ at $94^{\circ} \mathrm{C}$; annealing: $1 \mathrm{~min}$ at $55^{\circ} \mathrm{C}$; extension: $1 \mathrm{~min} 30$ at $72^{\circ} \mathrm{C}$ ) generating DNA fragments of 99 base pairs (bp). Ten $\mu l$ of the amplified DNA were then digested with 20 and 40 units Msp I, at $37^{\circ} \mathrm{C}$ for two and 16 hours respectively. Identification of digested polymerase chain reaction products was obtained by separation on $4 \%$ agarose MP (BoehringerMannheim) gel, staining with ethidium bromide, and visualisation under ultraviolet light. In the presence of the normal Ki-ras gene, the Msp I digestion generated a $78 \mathrm{bp}$ and a $21 \mathrm{bp}$ fragment; by contrast when the Msp I cutting site was changed by a point mutation at codon 12 , a persistent $99 \mathrm{bp}$ fragment was seen. Amplified samples from normal colonic mucosa and from the colonic carcinoma SW 480 cell line (which is known to carry the mutation at codon 12) were treated simultaneously as normal and positive controls, respectively. This method was reported to have a great sensitivity, detecting the presence of a point mutation in $5-10 \%$ of the cell population, although the nature of the mutation was not identified. ${ }^{19} 20$ Results can be obtained within 24 hours.

As this rapid method can in certain cases yield ambiguous results, caused by partial digestion (that is, when a faint $99 \mathrm{bp}$ band is seen after Msp I digestion), we performed direct sequencing to validate it; all polymerase chain reaction products showing persistence of a clear or faint $99 \mathrm{bp}$ band after digestion were submitted for direct sequencing to confirm the presence of point mutations at codon 12 .

\section{DIRECT SEQUENCING}

In brief, polymerase chain reaction products were ligated to $\mathrm{pCR}$ II vector using a TA Cloning Kit (Invitrogen Corporation, San Diego, CA, USA). One shot INV $\alpha \mathrm{F}^{\prime}$ competent cells (Invitrogen) were transformed with the pCR II vector containing polymerase chain reaction products using the same kit and plated on Luria-Bertani medium-Agar plates with ampicillin $50 \mu \mathrm{g} / \mathrm{ml}$ and X-Gal $40 \mathrm{mg} / \mathrm{ml}$ for selection.

Selected colonies were grown in LuriaBertani medium + ampicillin medium for DNA plasmid isolation using a Quiagen plasmid mini Kit (Quiagen Inc, Chatsworth, CA, USA). Polymerase chain reaction products were directly sequenced by the dideoxy chain termination sequencing method ${ }^{21}$ using Sequenase version 2.0 DNA sequencing Kit (United States Biochemical, Cleveland, Ohio) according to the manufacturer's instructions.

\section{CYTOLOGICAL EXAMINATION}

Results provided by $\mathrm{Ki}$-ras analysis were compared with those obtained by routine cytological examination. Cytological findings were classified by a pathologist blinded to the genetic analysis data, as malignant (=positive for malignant cells - malignancy deemed certain), suspicious (=presence of nuclear and cellular atypia suspicious of malignancy), benign (=negative for malignant cells) or not contributive (=insufficient cellular material collected or not adequate fixation).

\section{Results}

VALIDATION OF THE POLYMERASE CHAIN REACTION-RESTRICTION FRAGMENT LENGTH POLYMORPHISM ANALYSIS METHOD

After separation of the digested polymerase chain reaction products on agarose MP gel, four types of results were seen (Fig 2): (a) both 99 and $78 \mathrm{bp}$ bands of similar intensity (lane 1), $n=16$ patients; (b) faint $99 \mathrm{bp}$ band and a dominant 78 bp band (lane 2), $\mathrm{n}=8$ patients; (c) dominant $99 \mathrm{bp}$ band and a faint $78 \mathrm{bp}$ band (lane 3), $n=4$ patients; (d) one single 78 bp band (lane 4 ), $n=17$ patients.

In all 20 patients showing a clearly visualised $99 \mathrm{bp}$ band (type (a) and (c) results), mutations at codon 12 were confirmed by direct sequencing (Fig 2, sequences 1 and 3 ); the more frequent mutation detected was GTT in place of GGT.

By contrast, in the eight patients with type (b) results, we failed to detect any mutation (Fig 2, sequence 2). In addition, direct sequencing was performed in five patients with type (d) results where normal Ki-ras codon 12 
TABLE I Diagnostic findings and clinical outcome in patients with chronic pancreatitis $(n=16)$

\begin{tabular}{|c|c|c|c|c|c|c|}
\hline & $\begin{array}{l}\text { Location of the } \\
\text { stricture(s) at ERCP }\end{array}$ & Cytology & & $\begin{array}{l}\text { Ki-ras mutations } \\
\text { at codon } 12\end{array}$ & $C T / E U S$ & $\begin{array}{l}\text { Outcome } \\
\text { (month) }\end{array}$ \\
\hline 1 & Head $\dagger$ & Benign & \multirow{12}{*}{$\mathrm{n}=10$} & - & Normal & Good (14) \\
\hline 2 & Head and body & Benign & & - & $\begin{array}{l}\text { Cystic lesion of the head-Ca }{ }^{++} \\
\text {(about } 25 \mathrm{~mm} \text { ) }\end{array}$ & Good (11) \\
\hline 3 & Head-body* & Benign & & - & No mass- $\mathrm{Ca}^{++}$ & Good (10) \\
\hline 4 & Head $^{\star}$ & Benign & & - & Heterogeneous aspect of the & Good (11) \\
\hline 5 & Head and body* & Benign & & - & No mass-Ca $a^{++}$ & Good (10) \\
\hline 6 & Head $\star$ & Benign & & - & No mass- $\mathrm{Ca}^{+}$, & Good (10) \\
\hline 7 & Bodyt & Benign & & - & No mass-Ca ${ }^{++}$ & Good (9) \\
\hline 8 & Body* & Benign & & - & No mass-Ca ${ }^{++}$ & Good (11) \\
\hline 9 & Head $^{\star}$ & Benign & & - & Normal & Good (6) \\
\hline 10 & Head and bodyt & Benign & & - & No mass- $\mathrm{Ca}^{++}$ & Good (6) \\
\hline 11 & Head $^{\star}$ & Not contributive & & - & No mass-Ca ${ }^{++}$ & Good (11) \\
\hline 12 & Head $\dagger$ & Not contributive & & - & No mass & Good (11) \\
\hline 13 & Head $^{\star}$ & Not contributive & \multirow[t]{2}{*}{$\mathrm{n}=4$} & - & $\begin{array}{l}\text { Dilatation of the MPD and } \\
\text { its side branches }\end{array}$ & Good (9) \\
\hline 14 & Body-tail $\dagger$ & Non contribute & & - & Heterogenous aspect of the & Good (9) \\
\hline 15 & Head and bodyt & Suspicious & \multirow{2}{*}{$\mathrm{n}=2$} & - & Heterogeneous aspect of & Good (6) \\
\hline 16 & Head $\dagger$ & Suspicious & & - & $\begin{array}{l}\text { the boay } \\
\text { Cystic lesion of the head }\end{array}$ & Good (6) \\
\hline
\end{tabular}

^ERCP findings consistent with benign changes; $†$ ERCP findings = equivocal aspect; malignancy suspected; $\mathrm{CA}^{++}$pancreatic calcifications. $\mathrm{CT}=$ computed tomography, $\mathrm{EUS}=$ endoscopic ultrasonography, $\mathrm{MPD}=$ main pancreatic duct.

sequence was well confirmed (Fig 2, sequence 4). Considering that type (b) results constitute the potential source of false positives, it represents $17 \%$ (eight of 45 patients).

Results of Ki-ras analysis reported below are provided using both methods.

\section{KI-RAS MUTATIONS AT CODON 12 IN PANCREATIC BRUSHINGS}

\section{Chronic pancreatitis}

Table I details the diagnostic findings and clinical outcomes of chronic pancreatitis patients $(n=16)$. In eight of 16 patients with chronic pancreatitis, the diagnosis of benign stricture(s) was clearly suggested by ERCP while eight patients presented equivocal ERCP findings.
No pancreatic masses were detected by computed tomography, or endoscopic ultrasonography or both in all cases. Cytological findings were benign in 10 of 16 patients, non-contributory in four, and suspicious in two.

A definitive diagnosis of chronic pancreatitis was established by a regular follow up; all patients had a benign course (mean (SD) follow up: $9 \cdot 3(2 \cdot 2)$ months, range 6-14) and none showed evidence of $\mathrm{Ki}$-ras mutations at codon 12.

\section{Pancreatic adenocarcinoma}

Table II shows the data on pancreatic adenocarcinoma patients $(n=24): 14$ of 24 patients showed ERCP findings strongly suggestive of malignancy while 10 had inconclusive pancreatography.

TABLE II Comparison of point mutations detection with the cytological and radiological findings in patients with pancreatic adenocarcinoma $(n=24)$

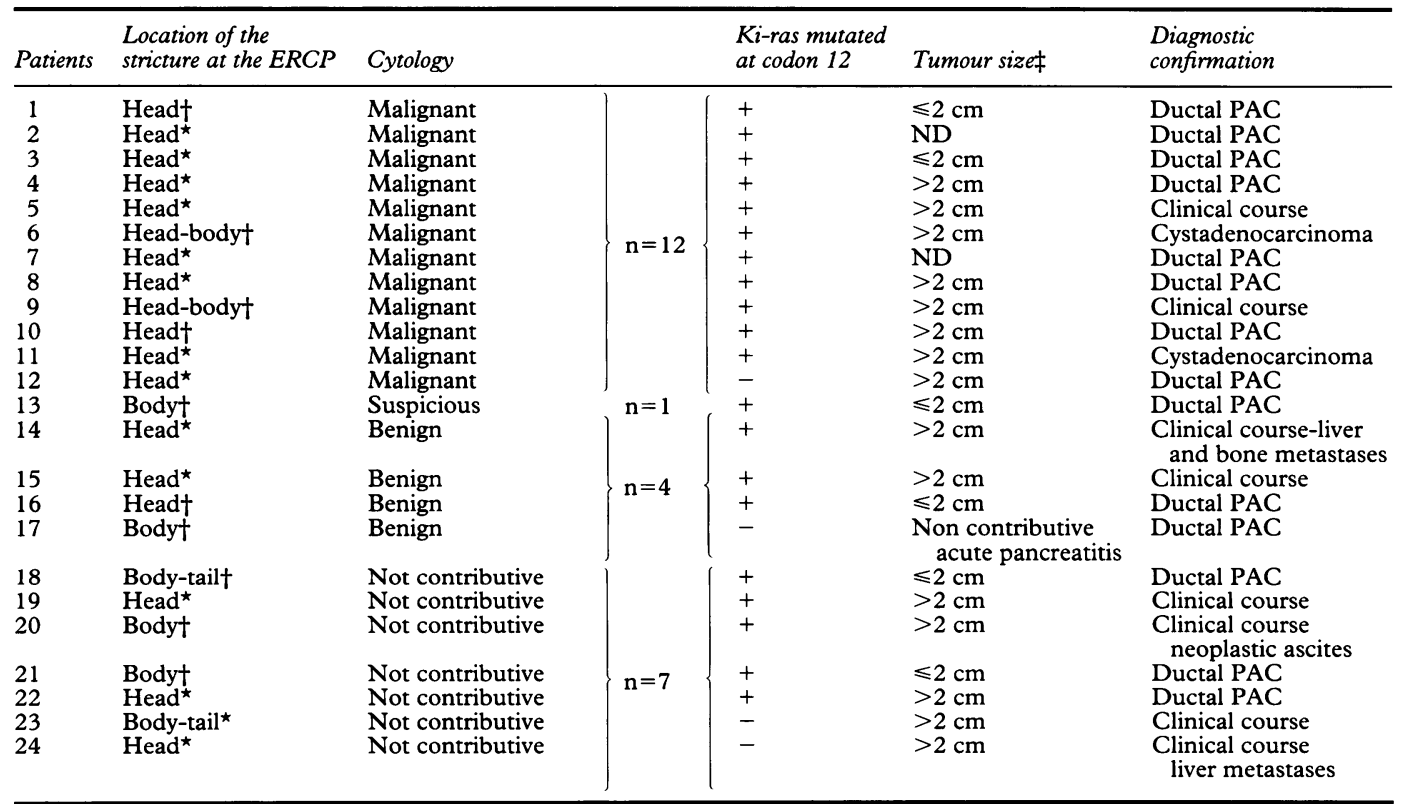

^ERCP findings, malignant stricture strongly suspected; †ERCP findings, equivocal aspect, malignancy suggested; łassessed by EUS or computed tomography. 
TABLE III Diagnostic findings and clinical outcome in patients with intraductal mucin hypersecreting neoplasm ( $n=5)$

\begin{tabular}{|c|c|c|c|c|c|}
\hline & $\begin{array}{l}\text { Location of the } \\
\text { lesions* at ERCP }\end{array}$ & Cytology & $\begin{array}{l}\text { Ki-ras mutations } \\
\text { at codon } 12\end{array}$ & $C T / E U S$ & Outcome (month) \\
\hline 1 & Tails & Benign, mild dysplasia $†$ & - & $\begin{array}{l}\text { Dilated MPD-heterogeneous } \\
\text { mass of the tail }\end{array}$ & $\begin{array}{l}\text { Good (12) after caudal } \\
\text { pancreatectomy }\end{array}$ \\
\hline 2 & Head\$ & Benign, mild dysplasia $†$ & - & $\begin{array}{l}\text { Multicystic dilatations of } \\
\text { MPD }\end{array}$ & $\begin{array}{l}\text { Good (14) after } \\
\text { duodenopancreatectomy }\end{array}$ \\
\hline 3 & Body $\neq$ & Benign, no atypia & - & Enlarged MPD & Good (11) \\
\hline 4 & Head $\ddagger$ & Benign, no atypia & - & $\begin{array}{l}\text { Cystic dilatations of the } \\
\text { secondary duct }\end{array}$ & Good (9) \\
\hline 5 & Head $\ddagger$ & Benign, no atypia & - & $\begin{array}{l}\text { Parenchymatous } \\
\text { atrophy-Ca }\end{array}$ & Good (11) \\
\hline
\end{tabular}

* = Substenosis + dilatations of the MPD and its side branches, mucin plugs; $\dagger=$ confirmed by histological examination; $\ddagger=$ ERCP findings consistent with benign changes; $\$=$ ERCP findings, equivocal aspect; malignancy suspected. $\ddagger=$ ERCP findings consistent with
Other abbreviations as in Table I.

Brushing samples were obtained from all strictures and DNA analysis showed the presence of the mutations in 20 of 24 patients $(83 \%)$ with pancreatic adenocarcinoma, including two of two cystadenocarcinoma. By contrast, malignancy was cytologically diagnosed or suspected in only 13 of 24 patients $(54 \%)$. Four of 24 patients $(17 \%)$ had benign changes (false negative cytology) and seven of $24(29 \%)$ non-contributive tests resulting from insufficient material or inadequate fixation (inconclusive cytology). When comparing both cytological and molecular methods, Ki-ras analysis confirmed malignant or suspicious cytological findings in 12 of 13 cases and failed in one. Moreover, molecular biological method detected Ki-ras mutation in eight of 24 patients with false negative $(n=3)$ or inconclusive $(n=5)$ cytological findings. Three patients with pancreatic adenocarcinoma had both negative genetic and cytological findings. Patient 17 with non-contributive ERCP and endoscopic ultrasonography findings required laparotomy for definitive diagnosis (Table II). Notably mutations were detected in six patients with small tumours $(\leqslant 2 \mathrm{~cm})$, which were successfully resected.

Intraductal mucin hypersecreting neoplasms Five patients with intraductal mucin hypersecreting neoplasm did not have point mutations (Table III). Two of them were suspected to have malignant degeneration and therefore had surgical resection. Histological tests showed intraductal mucin hypersecreting neoplasm with mild to moderate dysplasia.

TABLE IV Comparison of Ki-ras analysis and brush cytology in patients with chronic pancreatitis and pancreatic adenocarcinoma $(n=40)$

\begin{tabular}{|c|c|c|c|c|c|}
\hline & \multirow{2}{*}{$\begin{array}{l}\text { Ki-ras analysis } \\
\text { Cases with } \\
\text { mutation }(n)\end{array}$} & \multicolumn{4}{|c|}{ Brush cytology $\dagger$} \\
\hline & & Malignant & Suspicious & Benign & $\begin{array}{l}\text { Not } \\
\text { contributive }\end{array}$ \\
\hline $\begin{array}{l}\text { Chronic pancreatitis } \\
(n=16)\end{array}$ & 0 & 0 & 2 & 10 & 4 \\
\hline $\begin{array}{l}\text { Pancreatic adenocarcinoma } \\
(\mathrm{n}=24)\end{array}$ & 20 & 12 & 1 & 4 & 7 \\
\hline $\begin{array}{l}\text { Sensitivity (\%) } \\
\text { Specificity }(\%)\end{array}$ & $\begin{array}{r}83 \\
100\end{array}$ & $\begin{array}{l}76 \\
83\end{array}$ & & & \\
\hline $\begin{array}{l}\text { Positive predictive value } \\
(\mathrm{PPV})(\%)\end{array}$ & 100 & 86 & & & \\
\hline $\begin{array}{l}\text { Negative predictive value } \\
\text { (NPV) }(\%)\end{array}$ & 80 & 71 & & & \\
\hline Accuracy $(\%)$ & $90 \ddagger$ & 58 & & & \\
\hline
\end{tabular}
$\star=$ including polymerase chain reaction-restriction fragment length polymorphism
analysis + direct sequencing; $t=$ for the calculation of sensitivity, specificity, PPV, NPV, and analysis + direct sequencing; $\dagger=$ for the calculation of sensitivity, specificity, PPV, NPV, and accuracy,

$\ddagger=p \leqslant 0 \cdot 01$, using Fisher's exact test.
Three other older patients, with good clinical status did not experience complications such as secondary obstructive pancreatitis and are followed up by imaging techniques, including ERCP, endoscopic ultrasonography, and computed tomography, and brush cytology (mean (SD) follow up 11.4 (1.6) months, range 9-13). In the five cases, the tumour was thus considered as benign.

VALUE OF KI-RAS CODON 12 MUTATIONS DETECTION IN THE DIFFERENTIAL DIAGNOSIS BETWEEN PANCREATIC ADENOCARCINOMA AND CHRONIC PANCREATITIS

Table IV summarises the comparison of both molecular and cytological analysis in patients with pancreatic adenocarcinoma and chronic pancreatitis $(n=40)$ in terms of sensitivity, specificity, positive and negative predictive values, and accuracy.

Accuracy of Ki-ras analysis was significantly higher.

\section{Discussion}

ERCP is one of the best imaging techniques in the clinical diagnosis of pancreatic cancer and differentiation from chronic pancreatitis. ${ }^{34}$ Differentiating pancreatic adenocarcinoma from chronic pancreatitis can be quite difficult particularly when both diseases coexist. In our study, a significant number of patients showed equivocal ERCP findings and were deliberately selected because they required further investigations for a definitive diagnosis. This explains the high number of patients with inconclusive ERCP. Therefore, we have attempted to compare conventional cytological examination and detection of $\mathrm{Ki}$-ras mutations in specimens collected by endoscopic brushings.

Cytological examination of specimens obtained by endoscopic retrograde brushings or catheter aspiration has a reported sensitivity ranging from 50 to $76 \%$, thus limiting its usefulness as a definitive diagnostic test. ${ }^{7-9}$ Similarly, the yield of cytological diagnosis in our study remains limited with a low accuracy $(58 \%)$. Several factors could explain these disappointing results: cytological distinction between chronic pancreatitis and pancreatic adenocarcinoma is occasionally difficult because chronic pancreatitis can induce morphological changes similar to those seen in well differentiated adenocarcinoma. ${ }^{22}$ This explains the suspicious results found in two 
chronic pancreatitis patients, which were not confirmed by the clinical and radiological course and invalidated by $\mathrm{Ki}$-ras analysis. Accuracy of cytology examination also depends on the cytologist's expertise, quality, and number of cells, which may be damaged by contrast medium or inadequate fixation. ${ }^{9}$

The recent report of $\mathrm{Ki}$-ras oncogene point mutations in a high percentage of pancreatic adenocarcinoma has triggered a new wave of interest in this potential genetic marker for early diagnosis of malignancy. Several molecular biological methods using the polymerase chain reaction technique have been reported, ${ }^{11-1317}$ capable of detecting point mutations of $\mathrm{Ki}$-ras codon 12 . In this study, we have chosen to use the rapid and sensitive polymerase chain reaction-restriction fragment length polymorphism analysis method. This method uncovers codon 12 point mutations, present in only $5 \%$ of the cell population studied, composed, among others, of neoplastic, normal duct, and inflammatory cells. ${ }^{19} 20$ Polymerase chain reaction-restriction fragment length polymorphism results are available within 24 hours, offering a rapid screening test in clinical practice. One of the possible drawbacks of this technique, however, is the yield of false positive results caused by incomplete digestion of polymerase chain reaction products. In our study, the rate of false positive results was $17 \%$, which invariably corresponded to the persistence of a faint undigested $99 \mathrm{bp}$ band. As this type of result is inconclusive, it requires confirmation by another method. Therefore, direct sequencing of polymerase chain reaction products was successfully applied to validate our positive and equivocal data. This technique is more time consuming and requires about eight days to achieve.

This study shows that Ki-ras analysis, combining the rapid test and the confirmation method when necessary, is much more accurate than brush cytology. The main advantages of the technique are its objectivity and the lack of dependence on cell integrity and number. In four of 24 cases of pancreatic adenocarcinoma, however, point mutations were not shown. This may result from the absence of $\mathrm{Ki}$-ras mutations in the neoplastic cells as seen in some pancreatic adenocarcinoma or in non-ductal pancreatic adenocarcinoma. Incorrect positioning of the cytology brush, restricting efficient brushing of the neoplastic site is also possible and could explain negative results obtained from both methods in three patients.

The search for Ki-ras mutations in pancreatic ductal cells seems promising in the differential diagnostic of chronic pancreatitis and pancreatic adenocarcinoma particularly when the second occurs in a setting of chronic pancreatitis. This diagnostic challenge is of utmost clinical importance, given the recently shown increased pancreatic adenocarcinoma risk in pancreatic adenocarcinoma patients ${ }^{2}$ and the frequency of inconclusive pancreatographic and cytological findings. In an appreciable number of our patients showing equivocal ERCP findings, $\mathrm{Ki}$-ras analysis discriminated between benign and malignant strictures more specifically than cytology. Interestingly, as an increasing percentage of chronic pancreatitis patients have therapeutic endoscopic examinations, DNA analysis of ductal cells collected during these procedures might help in early detection of neoplasia. Kiras activation is reported to occur as an early event in pancreatic duct carcinogenesis as seen in the Syrian golden hamster model and as suggested by the frequency of Ki-ras codon 12 mutations (about 50\%) in mucous cell hyperplasia and in papillary hyperplasia, found in Japanese patients. ${ }^{1415}$ In this study, we found the mutation in six patients with small size tumours $(\leqslant 2 \mathrm{~cm})$. It is critical to assess in the future the effectiveness of this approach in early neoplasia detection. A longterm study of $\mathrm{Ki}$-ras mutations incidence in chronic pancreatitis patients and their relation to clinical, radiological, and cytological changes would be of interest.

A similar approach might be applicable to intraductal mucin hypersecreting neoplasm, although $\mathrm{Ki}$-ras mutation incidence in this disease is controversial and based on a limited number of patients. Differences exist between Japanese and occidental reports. The first ${ }^{23} 24$ found $\mathrm{Ki}$-ras mutations in respectively three of five and five of eight patients with intraductal papillary neoplasms while the second ${ }^{13}$ did not see any mutation in a series of five patients. Our results did not show the presence of the mutated $\mathrm{Ki}$-ras gene in the five patients with intraductal mucin hypersecreting neoplasm, which is similar to intraductal papillary neoplasm. ${ }^{1825}$ In this small series, Ki-ras analysis did not permit discrimination of chronic pancreatitis from intraductal mucin hypersecreting neoplasm while cytological findings were more suggestive. It should be emphasised, however, that none of our intraductal mucin hypersecreting neoplasms had histological or cytological features of severe dysplasia or atypia and were thus considered to have a favourable prognosis. As this type of neoplasm has a low malignant potential but is often responsible for the development of secondary obstructive pancreatitis, ${ }^{182526}$ we currently advocate tumour resection in young patients and serial follow up in older ones (above 70 years) by computed tomography, ERCP, and repeated cytological examinations of pancreatic juice or brushing samples. It might thus be useful to follow up such patients similarly using Ki-ras gene analysis.

In conclusion, molecular analysis of Ki-ras gene can be successfully performed on ERCP specimens. A first screening test can be obtained within 24 hours by polymerase chain reaction-restriction fragment length polymorphism analysis but the presence of mutations should be confirmed by direct sequencing in ambiguous cases. This molecular biological approach seems more accurate than cytology for detection of neoplastic cells and may represent an interesting addition to the diagnostic procedures for pancreatic cancer, especially in patients with ERCP and cytological findings 
that do not provide conclusive evidence of malignancy.

Whether this approach might be useful in detecting malignant changes earlier remains to be evaluated.

The authors thank $M$ Baize, $M D, M$ Delhaye, $M D$, and A Vandermeeren, MD for their help in collecting pancreatic brushings, C Azar, MD for reviewing the manuscript, and Francisca Martinez-Vadillo for her secretarial assistance.

$\mathrm{J}$ L Van Laethem was supported by a grant from the 'Fondation Erasme'. P Vertongen and J Van Rampelbergh are recipients of a doctoral fellowship from IRSIA (Communaute Française de Belgique).

1 Gudjonsson B. Cancer of the pancreas. 50 years of surgery. Cancer 1987; 60: 2284-303.

2 Lowenfels AB, Maisonneuve $P$, Cavallini G, Amman RW, Lankisch PG, Andersen JR, et al and the International Pancreatitis study group. Pancreatitis and the risk of pancreatic cancer. N Engl f Med 1993; 328: 1433-7.

3 Niederau C, Grendell JH. Diagnosis of pancreatic carcinoma. Imaging techniques and tumors markers. Pancreas 1992; 7: 66-86.

4 Shemesh E, Czerniak A, Nass S, Klein E. Role of endoscopic retrograde cholangiopancreatography in differentiating pancreatic cancer coexisting with chronic pancreatitis. Cancer 1990; 65: 893-6.

5 Palazzo L, Roseau G, Gayet B, Vilgrain V, Belghiti J, Fekete F, et al. Endoscopic ultrasonography in the diagnosis and staging of pancreatic adenocarcinoma: results of a prospective study with comparison to ultrasonography and CT scan Endoscopy 1993; 25: 143-50.

6 Rosch Th, Brais C, Gain Th, Feurbach S, Siewert JR, Schusdziarra V, et al. Staging of pancreatic and ampullary carcinoma by endoscopic ultrasonography. Comparison with conventional sonography, computed tomography and angiography. Gastroenterology 1992; 102: 188-99.

7 Venu RP, Geenen JE, Kini M, Hogan WJ, Payne M, Johnson $\mathrm{K}$, et al. Endoscopic retrograde brush cytology: a new technique. Gastroenterology 1990; 99: 1475-9.

8 Goodale RL, Gajl-Peczalaka K, Dressel T, Samuelson J. Cytologic studies for the diagnosis of pancreatic cancer. Cancer 1981; 47: 1652-5.

9 Nakaizumi A, Tatsuta $M$, Vehara $H$, Yamamoto $R$ Takenaka A, et al. Cytologic examination of pure pancreatic juice in the diagnosis of pancreatic carcinoma. Cancer 1992; 70: 2610-4.

10 McGrath JP, Capon DJ, Smith DH, Chen EY, Seeburg PH, Soeddel DV, et al. Structure and organisation of the human $\mathrm{Ki}$-Ras oncogene and a related pseudogene. Nature 1983; 304: 501-6.

11 Almoguera C, Shibata D, Forrester K, Martin J, Arnheim N, Perucho M. Most human carcinomas of the exocrine pancreas contain mutant c-Ki-ras genes. Cell 1988; 53: 549-54

12 Tada $M$, Omata $M$, Ohto $M$. Clinical application of ras gene mutation for diagnosis of pancreatic adenocarcinoma. Gastroenterology 1991; 100: 233-8.

13 Lemoine NR, Jain S, Hughes CM, Staddon SL, Maillet B, Hall PA, et al. Ki-ras oncogene activation in preinvasive pancreatic cancer. Gastroenterology 1992; 102: 230-6.

14 Cerny WL, Mangold KA, Scarpelli DG. Ki-ras mutation is an early event in pancreatic duct carcinogenesis in the Syrian golden hamster. Cancer Res 1992; 52: 4507-13.

15 Yanagisawa A, Ohtake K, Ohashi K, Hori M, Kitasawa T, Sugano $\mathrm{H}$, et al. Frequent c-Ki-ras oncogene activation in mucous cell hyperplasias of pancreas suffering from chronic inflammation. Cancer Res 1993; 53: 953-6.

16 Shibata D, Almoguera C, Forrester K, Dunitz J, Martin SE, Cosgrove MM, et al. Detection of c-K-ras mutations in fine needle aspirates from human pancreatic adenocarcinomas. Cancer Res 1990; 50: 1279-83.

17 Tada M. Omat M, Kawai S, Saisho H, Ohto M, Saiki RK et al. Detection of ras gene mutations in pancreatic juice and peripheral blood of patients with pancreatic adenocarcinoma. Cancer Res 1993; 53: 2472-4.

18 Rickaert F, Cremer M, Deviere J, Tavares L, Lambillotte $\mathrm{JP}$, Schroder $\mathrm{S}$, et al. Intraductal mucin-hypersecreting neoplasms of the pancreas. A clinicopathologic study of eight patients. Gastroenterology 1991; 101: 512-9.

19 Haliassos A, Chomel JC, Grandjouan S, Kruh J, Kaplan JC Kitzis A. Detection of minority point mutations by modified PCR technique: a new approach for a sensitive diag nosis of tumor-progr 17 : 8093-9.

20 Ando M, Takemura K, Maruyama M, Endo M, Iwama T, Yuasa Y. Mutations in c-K-ras 2 gene codon 12 during colorectal tumorigenesis in familial adenomatous polyposis. Gastroenterology 1992; 103: 1725-31.

21 Sanger F, Niklen S, Coulson AR. DNA sequencing with chain-terminating inhibitors. Proc Natl Acad Sci USA 1977; 74: 5463-7.

22 Tao LC. Liver and pancreas. In: Bibbo $M$, ed. Comprehensive cytopathology. Philadelphia: W B Saunders, 1991: 844

23 Tada M, Omata $M$, Ohto $M$. Ras gene mutations in intraductal papillary neoplasms of the pancreas: analysis in five cases. Cancer 1991; 67: 634-7.

24 Yanagisawa A, Kato Y, Ohtake K, Kitagawa T, Ohashi K, Hori $\mathrm{M}$, et al. c-Ki-ras point mutations in ductectatic-type mucinous cystic neoplasms of the pancreas. $\mathcal{f p}_{p} \mathcal{f}$ Cancer Res 1991; 82: 1057-60.

25 Morohoshi T, Kanda M, Asanuma K, Kloppel G. Intraductal papillary neoplasms of the pancreas: a clinicopathologic study of six patients. Cancer 1989; 64: 1329-35.

26 Agostini S, Choux R, Payan MJ, Sastre B, Sahel J, Clement JP. Mucinous pancreatic duct ectasia in the body of the pancreas. Radiology 1989; 170: 815-6. 